\title{
Islamic Montessori Curriculum Reconstruction
}

\section{Dina Julita}

Received: 14062021 / Accepted: 25062021 / Published online: 30062021

(C) 2021 Association of Indonesian Islamic Early Childhood Education Study Program

\begin{abstract}
Abstrak Pendidikan Anak Usia Dini (PAUD) Rumah Bermain Padi (RBP) Kota Bandung merekonstruksi Kurikulum Montesssori menjadi islami. Keunikan ini patut untuk diteliti. Tujuan penelitian untuk mengetahui perbandingan antara Pendidikan dalam Islam dengan Metode Montessori dan bagaimana rekonstruksi Kurikulum Montessori Islami di PAUD RBP dilakukan. Penelitian dilakukan dengan pendekatan kualitatif bermetode studi kasus dan studi pustaka. Hasil penelitian menunjukkan Islam dan Metode Montessori dapat dijalankan secara selaras. Dalam rekonstruksi Kurikulum Montessori Islami di PAUD RBP, Islam menjadi landasan kurikulum utama dan Metode Montessori menjadi landasan pendukungnya. Landasan tersebut menjadi acuan dalam merumuskan tujuan pendidikan. Berdasarkan tujuan pendidikan, pengembangan kurikulum dilakukan. Diawali dengan perencanaan yang dilakukan tim pengembang kurikulum. Selanjutnya guru mengimplementasikan kurikulum melalui perencanaan, pembelajaran, dan penilaian. Tahap terakhir adalah evaluasi menggunakan analisis SWOT yang hasilnya digunakan untuk penyempurnaan kurikulum. Seluruh tahap pengembangan kurikulum dilakukan dengan menghargai fitrah dan keunikan anak didik.
\end{abstract}

Kata Kunci: kurikulum, Montessori, PAUD, Islam, rekonstruksi kurikulum

Abstract Rumah Bermain (RBP) in Bandung City reconstructed the Montessori Curriculum to Islamic. This uniqueness is worth researching. The objective research was to compare Education in Islam and the Montessori Method and to overview the reconstruction of the Islamic Montessori Curriculum in RBP. The research was using a qualitative approach with case study methods and literature studies. The results show that Islam and the Montessori Method can be implemented in harmony. In the reconstruction of the curriculum in RBP, Islam became the main foundation and the Montessori Method as supporting foundation. The foundations become a reference in the formulation of educational objectives. Based on the objectives, curriculum development was conducted. Starting from curriculum objective conducted by the team. Furthermore, the teacher implements the curriculum as instructional plan, learning, and assessment. The final stage is an evaluation using SWOT analysis, the results of which are used to improve the curriculum. In all stages of curriculum development, students' uniqueness and nature are respected.

Keywords: curriculum, Montessori, PAUD, Islam, curriculum reconstruction

\section{Pendahuluan}

Di tengah antusiasme masyarakat terhadap Pendidikan Anak Usia Dini (PAUD) saat ini, Metode Montessori semakin populer diterapkan. Meskipun sudah berumur lebih dari 100 tahun, tapi Metode Montessori justru tak lekang waktu. Belum ada data mengenai jumlah PAUD yang menggunakan Metode Montessori di Indonesia, tapi PAUD yang menyematkan kata "Montessori" pada nama atau slogannya menjadi fenomena umum yang semakin sering ditemui saat ini. Ini menandakan Montessori menjadi daya tarik bagi orang tua untuk memilih PAUD untuk anaknya. Kepopuleran Montessori dalam dunia PAUD, tidak terlepas dari keistimewaan prinsip-prinsip pembelajaran Montessori yang berpusat pada anak sehingga anak menjadi mandiri, belajar sesuai dengan tingkatannya masing-masing, dan pembelajaran yang menghargai anak. Dalam Metode Montessori, anak adalah master dari pembelajaran yang ia lakukan. Guru 
hanyalah menjadi pengamat pembelajaran dan perkembangan anak sekaligus fasilitator dan pengurus ruang belajar. (Gettman, 2016; Hiles, 2018; Montessori, 2004).

Oleh karena Metode Montessori berpusat pada anak, maka Kurikulum Montessori merupakan kurikulum yang berorientasi pada siswa. Kurikulum yang berorientasi siswa, dalam perspektif psikologis adalah kurikulum yang mengembangkan seluruh pribadi manusia sehingga siswa dapat menjadi manusia seutuhnya (humanistik). Dalam pandangan Montessori, anak dapat tumbuh menjadi manusia seutuhnya dengan memuaskan insting dan kebutuhan anak. Melalui prinsip itu, kelak anak akan menjadi orang dewasa yang terpenuhi dan seimbang. Dengan demikian ia dapat menjadi warga dunia yang membawa tatanan sosial menjadi lebih baik, yang mana merupakan representasi dari manusia seutuhnya (Ahmad, 2016; Gettman, 2016; Sanjaya, 2008).

Di Indonesia, Kurikulum Montessori tak jarang diadaptasi agar sesuai dengan nilai-nilai dan karakter sekolah. Satu di antara bentuk penyesuaian yang dilakukan terhadap Kurikulum Montessori adalah menyelaraskannya dengan nilai-nilai keislaman. Dalam konteks pengembangan kurikulum, agama dapat menjadi landasan filosofi kurikulum. Landasan kurikulum merupakan gagasan atau kepercayaan yang menjadi sasaran, dasar, titik tolak, suatu prinsip yang mendasari pengembangan kurikulum (Hornby dkk. dalam Sukirman dan Asra, 2016). Terkait hal tersebut. dikarenakan Indonesia merupakan negara dengan mayoritas muslim, menjadi hal yang wajar ketika nilai-nilai keislaman turut mewarnai pendidikan di Indonesia.Ini sesuai dengan pernyataan dalam Undang-Undang No 20 Tahun 2003 tentang Sistem Pendidikan Nasional yang mengungkapkan bahwa pendidikan nasional berakar pada nilai-nilai agama.

Penyelarasan Kurikulum Montessori dengan Islam menjadi hal yang menarik karena keduanya merupakan entitas yang berbeda. Pendidikan dalam Islam bersumber dari keilahian yakni Allah SWT, sementara Metode Montessori berasal dari buah pemikiran seorang manusia bernama Maria Montessori (Julita \& Susilana, 2018). Dengan perbedaan tersebut, Metode Montessori dan Pendidikan dalam Islam bisa jadi selaras, atau malah berlawanan. Oleh karena itu, untuk memadukan keduanya diperlukan rekonstruksi Kurikulum Montessori. Artinya Kurikulum Montessori dibangun kembali menjadi sesuatu yang baru, yang bersifat islami.

Salah satu lembaga PAUD yang merekonstruksi Kurikulum Montessori menjadi islami adalah Rumah Bermain Padi (RBP) di Jln. Cigadung Raya Timur No. 106, Kota Bandung. Kurikulum yang dikembangkan lembaga yang berdiri sejak tahun 2007 ini merupakan Kurikulum Montessori bernafaskan Islam, yang mana tercermin dari slogannya, "Sekolah Montessori Bernafaskan Islam". Lazimnya, pendidikan dengan metode Montessori menggunakan pendekatan sekuler atau bersikap netral terhadap pengenalan agama. Akan tetapi, di RBP, Islam menjadi "nafasnya" karena Montessori diintegrasikan dengan nilai-nilai Islam. Dengan kondisi tersebut, maka terdapat perbedaan antara Kurikulum Montessori pada lazimnya dengan Kurikulum Montessori yang ada di RBP. Keunikan ini patut untuk diteliti untuk mengetahui bagaimana perbandingan antara Pendidikan dalam Islam dengan Metode Montessori, landasan Kurikulum Montessori Islami di PAUD RBP, dan pengembangan Kurikulum Montessori Islami di PAUD RBP. Dengan demikian akan diketahui mengenai rekonstruksi Kurikulum Montessori Islami di PAUD Rumah Bermain Padi. Hasil Penelitian ini diharapkan dapat memberikan gambaran bagaimana Kurikulum Montessori dapat dilaksanakan selaras dan berpadu dengan Islam.

\section{Metode}

Metode yang digunakan dalam penelitian adalah pendekatan kualitatif. Alasan penggunaan metode kualitatif ialah karena pendekatan ini lebih sesuai untuk mendapatkan data tentang aspek-aspek yang akan diteliti. Dikatakan Creswell (2014) \& Moleong (2017) tujuan penelitian kualitatif adalah untuk mengeksplorasi dan memahami persoalan subjek penelitian, baik itu individu atau kelompok, contohnya perilaku, motivasi atau tindakan lainnya secara holistik. Dalam penelitian ini, aspek yang dieksplorasi dan dipahami adalah rekonstruksi Kurikulum Montessori Islami yang dilakukan guru dan Kepala PAUD di RBP. 
Sementara itu, bentuk penelitian kualitatif yang dilakukan Peneliti ialah studi kasus dengan didukung studi literatur. Format studi kasus digunakan kerena Peneliti mengamati objek penelitian tunggal, yakni rekonstruksi Kurikulum Montessori Islami yang terjadi di PAUD RBP. Dengan penelitian studi kasus, Peneliti berusaha mengamati, memahami, dan menganalisa rekonstruksi kurikulum yang dilakukan oleh subjek penelitian, yaitu kepala PAUD dan guru. Alasan Kepala PAUD dan guru menjadi subjek penelitian karena mereka adalah pelaku atau aktor yang berperan dalam merekonstruksi kurikulum, yaitu sebagai pengembang kurikulum di RBP.

Dalam penelitian studi kasus, prosedur pengumpulan data yang dipakai dalam penelitian ini adalah wawancara mendalam, observasi/ pengamatan, dan studi dokumentasi. Proses menganalisis data dimulai dari menelaah, kemudian mereduksi data dengan cara abstraksi Selanjutnya, data disusun ke dalam satuan-satuan yang kemudian dikategorisasi sambil melakukan koding. Setelah pengkodingan, data diperiksa keabsahannya dengan melakukan triangulasi data. Terakhir, data ditafsirkan menjadi teori substantif dengan menggunakan beberapa metode tertentu (Moleong, 2017).

Sementara itu, studi literatur dilakukan Peneliti untuk menjawab pertanyaan penelitian mengenai perbandingan antara pendidikan dalam Islam dan Kurikulum Montessori. Studi literatur merupakan cara yang sistematis dalam mengumpulkan dan mensitesis penelitian sebelumnya (Snyder, 2019). Pendekatan studi literatur digunakan oleh Peneliti karena metode ini merupakan cara terbaik untuk mensitesis temuan penelitian sebelumnya mengenai gambaran pendidikan dalam Islam dan Kurikulum Montessori. Dengan itu Peneliti dapat mendapatkan pemahaman untuk mengungkap area (pertanyaan penelitian) selanjutnya yakni rekonstruksi Kurikulum Montessori Islami. Terdapat empat tahap dalam studi literatur, yaitu mendesain kajian, melakukan kajian, menganalisis, dan menulis hasil kajian (studi) (Snyder, 2019).

Untuk pemeriksaan keabsahan data, setelah melewati tahap analisis, Peneliti menempuh tahap tahap triangulasi data. Dikatakan Patton dalam Moleong (2017) dalam penelitian kualitatif triangulasi dilakukan dengan membandingkan dan mengecek balik derajat kepercayaan suatu informasi yang diperoleh. Dalam melakukan riset, penelitian ke lapangan dilakukan pada tahun 2018 yang dilanjutkan dengan kajian literatur pada tahun 2021.

\section{Hasil Penelitian}

\section{Perbandingan Pendidikan dalam Islam dengan Metode Montessori}

Pendidikan dalam Islam dan Kurikulum Montessori merupakan sesuatu yang berbeda. Dalam melaksanakan pendidikan, Islam berpedoman kepada Al Quran dan Assunah, sementara Metode Montessori bersandar pada gagasan pendidikan yang dilatarbelakangi pengalaman hidup seorang nasrani bernama Maria Montessori. Dengan perbedaan latar belakang itu, berikut perbandingan antara Pendidikan dalam Islam dan Metode Montessori.

Tabel 1. Perbandingan Pendidikan dalam Islam dengan Metode Montessori

\begin{tabular}{|c|c|c|c|}
\hline No & Topik & Pendidikan dalam Islam & Metode Montessori \\
\hline 1 & $\begin{array}{l}\text { Tujuan } \\
\text { Pendidikan }\end{array}$ & $\begin{array}{l}\text { a. Anak menemukan keseimbangan } \\
\text { dari semua aspek: kepercayaan, } \\
\text { kesehatan mental, intelektual, } \\
\text { spiritual, moral dan kemanusiaan } \\
\text { b. Anak tumbuh menjadi manusia } \\
\text { yang baik (good man): keimanan } \\
\text { dan ketakwaan } \\
\text { c. Mendapatkan keselamatan dunia } \\
\text { akhirat }\end{array}$ & $\begin{array}{l}\text { a. Keseimbangan harmonis antara } \\
\text { perkembangan biologis. } \\
\text { b. Anak tumbuh menjadi warga } \\
\text { dunia yang membawa tatanan } \\
\text { sosial yang baik }\end{array}$ \\
\hline 2 & $\begin{array}{l}\text { Pandangan } \\
\text { terhadap } \\
\text { potensi anak }\end{array}$ & $\begin{array}{l}\text { Anak telah membawa fitrahnya } \\
\text { sejak lahir, yang merupakan } \\
\text { potensi dasar yang perlu } \\
\text { dikembangkan }\end{array}$ & $\begin{array}{l}\text { Anak mengalami fase embrio } \\
\text { spiritual dengan energi nebula } \\
\text { dan memiliki alat bantu belajar } \\
\text { yaitu "pikiran penyerap" dan } \\
\text { "periode sensitif". }\end{array}$ \\
\hline
\end{tabular}


3 Lingkungan Orang tua, guru, dan lingkungan pendidikan sosial

$4 \quad$ Konsep penghargaan

dan

hukuman

(reward and

punishment)

5 Konsep

kebebasan

dalam

belajar
Memberikan pilihan bebas dalam mengajar
Lingkungan terstruktur, kelas campur usia, orang dewasa sebagai fasilitator dan pengamat.

Terdapat reward and punishment, tapi untuk anak usia dini hanya diberikan penghargaan.

Tidak mengenal reward and punishment.
Tidak ada paksaan kepada anak dalam memilih tapi menjadi orang beriman dan bertakwa adalah suatu keharusan.

Sumber: diolah dari data penelitian

Dari segi tujuan pendidikan, Islam dan Metode Montessori sama-sama ingin membentuk anak agar menjadi manusia yang menemukan keseimbangan diri. Akan tetapi, ada perbedaan dalam mendefinisikan "keseimbangan diri" antara keduanya.

Dalam Islam, pendidikan bertujuan agar anak menemukan keseimbangan diri dari berbagai aspek, mulai dari kepercayaan, kesehatan mental, intelektual, spiritual, moral dan kemanusiaan sehingga anak dapat tumbuh mejadi manusia yang baik (good man) berdasarkan keimanan dan ketakwaan kepada Allah, sesuai dengan Al Quran dan As-Sunah. Untuk mencapai keseimbangan pada seluruh aspek tersebut, diperlukan harmoni antara tiga dimensi: akal, pikiran, dan iman. Hal itu akan mengantarkan manusia pada kemajuan hidup umat yang mana merupakan tugas setiap muslim. Dengan itu manusia akan mencapai keselamatan dunia dan akhirat. (Padjrin, 2016; Rayan, 2012; Salleh \& Khamis, 2010; Yasin \& Jani, 2013).

Sementara itu, keseimbangan yang dimaksudkan dalam Metode Montessori anak mencapai keseimbangan yang harmonis antara perkembangan biologis dan sosiologis. Dari segi biologis, tujuan pendidikan ialah untuk mencapai perkembangan anak yang alami, sedangkan dari segi sosial tujuannya adalah untuk menyiapkan anak-anak untuk siapa menghadapi lingkungan mereka. Dengan tumbuh menjadi manusia yang terpenuhi dan seimbang, kelak seorang anak akan mampu menjadi warga dunia yang membawa tatanan sosial menjadi lebih baik, yang mana merupakan representasi dari manusia seutuhnya (Montessori, 2015; Ahmad, 2016).

Terkait potensi anak, Pendidikan dalam Islam memahami bahwa anak telah membawa fitrahnya sejak lahir, yang mana fitrah tersebut merupakan potensi dasar anak yang perlu dikembangkan melalui pendidikan. Oleh karena itu, anak perlu dididik sedini mungkin dalam menumbuhkan seluruh potensi dasar (fitrah) anak. Pendidikan Islam harus dapat mengaktifkan dan mengoptimalkan potensi rohaniah, tidak hanya potensi jasmaniahnya, dalam upaya melaksanakan tugas manusia sebagai khalifah di bumi (Mohammad Muchlis, 2007).

Dalam Metode Montessori anak dipandang membawa potensinya sejak lahir. Potensi ini diistilahkan Montessori sebagai embrio spiritual, fase awal yang dilewati sejak anak lahir. Dalam masa embrio spiritual, anak yang baru terlahir memiliki energi potensial yang disebut "nebula". Nebula merupakan energi kreatif yang akan membimbing anak untuk "menyerap" lingkungannya". Terkait hal itu ada dua "alat bantu" yang dimiliki pada embrio spiritual, yakni "pikiran penyerap" dan periode sensitif. Pikiran penyerap merupakan kemampuan anak menyerap keterampilan dengan cepat dan tepat, sedangkan periode sensitif merupakan periode peka dan kesenangan dalam mengulang sesuatu sebagai suatu proses, bukan sebagai tujuan. Misalnya pada usia 1,5-4 tahun anak sedang mengalami periode berjalan. Di masa itu anak suka melakukan proses berjalan, bahkan bukan berjalan untuk mencapai suatu tempat (Azkia \& Rohman, 2020; Hilson, 1982; Montessori, 2008).

Untuk mengembangkan potensi anak, Pendidikan dalam Islam dan Metode Montessori sepakat menyebutkan bahwa lingkungan menjadi kuncinya. Menurut Islam, terdapat tiga 
lingkungan yang membentuk anak, yaitu orang tua, guru, dan lingkungan sosial. Orang tua merupakan pendidik pertama bagi anak dan setelahnya adalah guru. Dalam mendidik, orang tua dan guru disyaratkan mampu menjadi teladan bagi anak. Selain itu, lingkungan sosial yakni tetangga dan teman sepermainan juga penting dalam membentuk kepribadian yang baik bagi anak (Atabik \& Burhanuddin, 2015; Jailani, 2014; Padjrin, 2016; Sulaiman, 2014).

Dalam pandangan Montessori, lingkungan pun dianggap berperan sangat penting dalam perkembangan anak karena anak memiliki ketertarikan terhadap lingkungannya termasuk orangorang di dalamnya (Hilson, 1982). Dalam Metode Montessori, lingkungan pendidikan dikenal dengan istilah "lingkungan siapan" (prepared environment). Lingkungan siapan adalah lingkungan yang terstruktur. Pada setiap area belajar di kelas Montessori terdapat alat kerja (alat belajar) untuk mendukung tercapainya tujuan pembelajaran. Setiap alat kerja disusun ke dalam rak-rak sesuai dengan tingkatannya dan dapat digunakan dengan bebas oleh anak. (Lillard, 2013). Lingkungan siapan selanjutnya adalah percampuran anak-anak didik dalam berbagai usia (dini) ke dalam satu kelas. Kondisi ini mendukung pembelajaran yang bersifat individual sesuai perkembangan anak, bukan berdasarkan usia. Selanjutnya, dukungan orang dewasa pun menjadi bagian dari lingkungan siapan. Di dalam kelas, guru sebagai orang dewas bertindak sebagai pengurus, fasilitator, dan pengamat pekerjaan dan perkembangan anak (Liliard dalam Ansari \& Winsler, 2014).

Terkait dengan reward and punishment (penghargaan dan hukuman), Islam mengenal konsep ini. Dalam Islam, Pendidik perlu mengapresiasi segala perbuatan baik, begitu pula dengan sanksi yang perlu diberikan agar anak menjadi disiplin dalam menjalankan aturan. Akan tetapi, untuk anak usia dini Islam tidak memberikan hukuman dalam mendidik. Untuk mendisiplinkan anak usia dini dapat diberikan nasihat dan teguran saat berbuat hal yang tidak diharapkan. Sementara itu, penghargaan bisa diberikan kepada anak usia dini dengan tidak secara berlebihan, tapi cukup untuk meningkatkan motivasi. Bentuk penghargaan dapat berupa hadiah, pujian, sanjungan, senyuman dan segala perkataan serta perilaku yang menunjukkan apresiasi kepada anak (Gumiandari et al., 2019; Safitri, 2017).

Sementara itu, Metode Montessori tidak mengenal konsep reward and punishment ini. Pemberian penghargaan dan hukuman dinilai tidak efektif dalam mendidik anak. Pendidikan akan efektif jika motivasi anak datang dari dirinya sendiri. Oleh karena itu, dalam Metode Montessori, tidak terdapat penghargaan ekstrinsik, misalnya berupa hadiah. Montessori percaya bahwa kondisi bebas memilih dalam belajar merupakan penghargaan intristik yang dibutuhkan anak. (Lillard, 2013; Montessori, 2004).

Dalam belajar, pilihan bebas merupakan salah satu prinsip Metode Montessori. Diyakini Montessori, pembelajaran hanya terjadi saat anak memiliki pilihan bebas. Dengan prinsip itu anak didik dapat memilih objek dan kegiatan yang telah disediakan oleh guru atau fasilitator. Tidak ada paksaan bagi anak-anak untuk memilih aktivitas. Jika anak melakukan aktivitas di luar harapan guru, guru mengarahkan anak dengan cara yang tidak kentara agar kembali kepada agenda pembelajaran. Prinsip ini tidak bertentangan dengan Islam. Islam memberikan kebebasan untuk memilih jalannya termasuk pendidikan, tapi manusia wajib untuk mempertanggungjawabkan pilihannya tersebut. Oleh karena itu penting dalam pendidikan untuk mengutamakan keimanan dan ketaqwaan dalam pendidikan anak (Aslam, 2017; Lillard, 2013).

\section{Landasan Kurikulum Montessori Islami di PAUD RBP}

Dalam mengembangkan kurikulum, rekonstruksi Kurikulum Montessori Islami di PAUD RBP sangat terkait dengan landasan yang ditanamkan oleh Kepala PAUD, yakni JMA. Latar pengalamannya yang unik sebagai seorang individu, membangun bentuk Kurikulum Montessori yang diterapkan di RBP. Hal ini dapat dipahami karena JMA merupakan inisiator, pendiri, pemilik, dan pemimpin PAUD RBP. Dengan peran tersebut tentu saja JMA memiliki otoritas dalam menentukan bentuk kurikulum yang ingin diimplemetasikan di PAUD RBP.

JMA mempelajari metode Montessori melalui kursus Montessori dengan praktek mengajar 420 jam di First Impression Montessori School di London. Selanjutnya, ia mengajar Montessori di London, Inggris dan Kota Bandung, Indonesia. Selama di London, JMA juga 
menjadi guru agama/mengaji anak di Inggris. Berdasarkan pengalaman tersebut, JMA memutuskan prinsip-prinsip yang dipegangnya terhadap Kurikulum Montessori.

Tabel 2. Asas Landasan Kurikulum Montessori Islami di PAUD Rumah Bermain

\begin{tabular}{|c|c|c|}
\hline $\begin{array}{c}\text { Penentu } \\
\text { Kebijakan }\end{array}$ & $\begin{array}{c}\text { Pandangan terhadap Pendidikan Anak- } \\
\text { Montessori }\end{array}$ & Implikasi terhadap Kurikulum \\
\hline $\begin{array}{l}\text { Kepala } \\
\text { PAUD }\end{array}$ & $\begin{array}{l}\text { 1. Memiliki sikap setuju dan tidak setuju } \\
\text { terhadap Kurikulum Montessori } \\
\text { konvensional. } \\
\text { a. Menyetujui prinsip setiap anak } \\
\text { adalah unik, mendidik anak } \\
\text { mandiri dan sesuai fitrah (embrio } \\
\text { spiritual). } \\
\text { b. Tidak menyetujui untuk merayakan } \\
\text { berbagai hari raya keagamaan, } \\
\text { mengenalkan nilai moral positif } \\
\text { lokal semata, tidak mengenal tata } \\
\text { cara ibadah sesuai agama yang } \\
\text { dianut anak-orang tua } \\
\text { 2. Metode Alif dalam penanaman } \\
\text { akidah anak usia dini }\end{array}$ & $\begin{array}{l}\text { 1. Memberikan muatan } \\
\text { penanaman akidah dan akhlak } \\
\text { dengan menggunakan Metode } \\
\text { Alif sebagai referensi } \\
\text { 2. Pengenalan praktik ibadah } \\
\text { 3. penyebutan nama Allah SWT } \\
\text { dalam setiap kegiatan } \\
\text { pembelajaran } \\
\text { 4. pelaksanaan pembelajaran } \\
\text { sesuai dengan fitrah anak, } \\
\text { baik fitrah iman, fisik } \\
\text { maupun jiwa anak. }\end{array}$ \\
\hline
\end{tabular}

Sumber: diolah dari data penelitian

Ada tiga pokok prinsip Montessori yang disetujui JMA karena sejalan dengan konsep Islam. Pertama, prinsip Montessori yang menghargai anak dengan menganggap setiap anak itu unik. Menurut dia, Allah SWT menciptakan setiap manusia berbeda-beda sesuai dengan tujuannya masing-masing. Dengan menghargai anak sebagai pribadi yang unik, maka pembelajaran yang dilaksanakan di PAUD RBP pun dilaksanakan sesuai dengan fitrah anak, baik fitrah iman, fisik maupun jiwa anak (PAUD Rumah Bermain Padi, 2017).

Kedua, JMA juga sepakat dengan metode Montessori yang menempatkan anak sebagai individu mandiri. Dengan melatih keterampilan hidup dan pengetahuan lainnya anak dapat membantu dirinya sendiri dalam kegiatan sehari-hari dan meminimalisir bantuan orang dewasa. Artinya, ia siap menghadapi lingkungannya. Konsep ini serupa dengan hadist Nabi Muhammad SAW yang menyatakan, "Sebaik baik manusia adalah yang paling bermanfaat bagi orang lain" (HR. Qudhy dari Jabir dalam Khulaisie, 2016, p. 86).

Ketiga, pada Metode Montessori anak dididik dengan memanfaatkan fase embrio spiritual (enam tahun pertama kehidupan anak). Pada masa ini anak tengah mengalami periode sensitif. Montessori menggagas teori mengenai masa di mana anak melakukan suatu tindakan yang berulang-ulang dan kemudian mendapatkan suatu keterampilan secara cepat. Inilah yang disebut dengan periode sensitif. JMA berpendapat, pembelajaran dengan memperhatikan periode sensitif sejalan dengan mendidik anak sesuai fitrah, yakni mendidik anak sesuai dengan tumbuh kembangnya. Pada setiap anak, periode sensitif akan dilewati secara berbeda-beda, meskipun umumnya masih berada pada jalur yang sama. Periode sensitif tiap anak harus diperhatikan oleh guru Montesssori dalam mendidik yang mana mempertegas anak dididik sesuai dengan fitrahnya.

Meski setuju dengan metode Montessori, ada beberapa konsep utama yang mengganjal bagi JMA karena tidak sesuai dengan konsep Islam.

Pertama, berdasarkan pengalamannya mengajar, sekolah dengan metode Montessori selalu memiliki program merayakan semua hari raya agama yang dianut oleh murid-muridnya. Ia menyatakan pengaruh terpaan dari banyaknya hari raya yang dirayakan sekolah tidak memberikan hal yang positif untuk akidah anak muslim.

Kedua, konsep yang tidak disetujui JMA adalah prinsip metode Montessori yang harus merujuk pada nilai positif lokal. Pada mulanya prinsip ini tidak dianggapnya masalah, sampai suatu ketika, saat JMA menjadi guru di sekolah Montessori di London, homoseksual dilegalkan 
di Inggris di bawah pemerintahanan baru Perdana Menteri Toni Blair dari Partai Buruh. Dampak dari pelegalan homoseksual tersebut terbawa kepada dunia pendidikan. Saat menjelaskan topik tentang pernikahan, sekolah di Inggris harus menjelaskan definisi pernikahan tidak hanya dilakukan lawan jenis tapi juga dengan sesama jenis. Mengalami hal itu, JMA menyatakan PAUD di Rumah Bermain Padi hanya akan merujuk pada nilai moral lokal yang tidak bertentangan dengan Islam. Ia menempatkan nilai Islam di atas prinsip Montessori.

Ketiga, konsep yang tidak disetujui JMA pada kurikulum Montessori adalah sikapnya yang netral terhadap agama. Meskipun sekolah merayakan semua hari raya keagamaan, tapi tata cara ibadah sesuai agamanya masing-masing tidak diajarkan. Kegiatan bernuansa religi yang dilakukan anak-anak di sekolah Montessori adalah berdoa, dan doa yang diucapkan dalam kegiatan sehari-hari adalah doa yang bersifat umum tidak merujuk kepada agama apapun.

Pandangan JMA terhadap Kurikulum Montessori tersebut kemudian menjadi acuan dalam merekonstruksi Kurikulum Montessori Islami di PAUD RBP, termasuk dalam menentukan visi-misi serta perumusan kurikulum.

Berdasarkan acuan yang ditetapkan, visi dari Rumah Bermain Padi adalah "menjadi suatu lembaga yang seluruh komponennya merupakan penyejuk dan bermanfaat bagi lingkungannya (rahmatan lil'alamin)". Sementara misi Rumah Bermain Padi adalah mengantarkan anak didik menjadi muslim/muslimah yang bersyukur, mandiri, berpikir kreatif, dan senang belajar; memberikan pembelajaran dengan stimulasi yang maksimal; menyampaikan kurikulum nasional yang dikombinasikan dengan prinsip-prinsip Montessori dalam pembelajaran bernuansa Islami.

Sementara itu, dalam merumuskan kurikulum, titik mula Kurikulum Montessori Islami di RBP ialah berbentuk kurikulum yang dirumuskan serupa dengan sekolah Montessori di Inggris sesuai dengan pengalaman JMA, dengan terdapat beberapa perbedaan, yaitu dengan menambahkan materi praktik ibadah dan akidah setiap hari Jumat.

Sumber materi praktik ibadah dan akidah adalah Metode Alif yang yang dikembangkan oleh Keluarga Islam di Britania Raya dan Sekitarnya (KIBAR), yakni metode Alif. Metode Alif pernah dipelajari dan diterapkan oleh JMA ketika menjadi guru mengaji anak-anak di Inggris. Tujuan dari pelaksanaan metode Alif adalah untuk menanamkan Aqidah Islamiyah kepada anak melalui aktivitas belajar anak aktif. Metode ini memberi pengaruh terhadap nilai Islam yang diprioritaskan dalam kurikulum yang diimplementasikan di PAUD Rumah Bermain Padi, yaitu akidah dan akhlak.

Tidak hanya terdapat materi praktek akidah pada hari Jumat, kurikulum juga memuat penanaman akidah dalam keseharian pembelajaran, tidak hanya ada pada sesi pengenalan agama Islam saja. Berikut kutipan terkait, "Implikasinya adalah nama Allah disebut. Pada memulai praktik guru mengucapkan Bismillahirrahmanirrahim, selesai Alhamdulillahirabbil 'alamin. Atau saat menjelaskan sesuatu, nama Allah disebutkan. Kutipan tersebut mengungkapkan, konsep Kurikulum Montessori Islami di RBP merupakan proses mendekatkan Allah dengan keseharian anak-anak. Semua yang ditemui, dilihat, termasuk dirinya sendiri adalah ciptaaan Allah SWT.

Selanjutnya, dalam perjalanannya PAUD Rumah Bermain Padi juga harus menentukan definisi nilai Islam pada Kurikulum Montessori Bernafaskan Islam. Berdasarkan wawancara dengan Kepala PAUD pada 11 April 2018, nilai Islam yang dipegang oleh PAUD Rumah Bermain Padi adalah tidak menganut aliran apapun. "Asal syahadatnya masih sama Insya Alllah. ...yang membuat kita sama syahadat, yaitu akidah." ujar Kepala PAUD. Diketahui pula, PAUD Rumah Bermain Padi memutuskan kebijakan untuk lebih mengutamakan pengenalan akidah (keimanan kepada Allah) dan akhlak (budi pekerti) dibandingkan fiqih (tata cara ibadah) dalam Kurikulum Montessori Islami.

Berdasarkan perumusan itu, maka Kurikulum Montessori Islami yang dilaksanakan di PAUD RBP memuat penanaman akidah, praktik ibadah, penyebutan nama Allah SWT dalam setiap kegiatan pembelajaran, pelaksanaan pembelajaran sesuai dengan fitrah anak, baik fitrah iman, fisik maupun jiwa anak. 
Demikian asas landasan Kurikulum Montessori Islami di PAUD RBP. Dalam merekonstruksi kurikulum, Kepala PAUD berperan besar dalam menentukan landasan kurikulum yang berakar dari persepsinya mengenai pendidikan. Persepsi yang berasal dari pengalaman pribadinya berimplikasi pada bentuk Kurikulum Montessori Islami.

\section{Pengembangan Kurikulum Montessori Islami di PAUD RBP}

Dalam pengembangan kurikulum, terdapat tiga tahap utama, yaitu perencanaann, implementasi, dan evaluasi kurikulum. Berdasarkan hasil penelitian, tahap-tahap tersebut dapat digambarkan ke dalam tabel di bawah ini:

Tabel 3. Proses Pengembangan Kurikulum Montessori di PAUD Rumah Bermain Padi

\begin{tabular}{|c|c|c|}
\hline Tahap & Pelaksana & Keterangan \\
\hline Perencanaan & Tim Pengembang & 1.Penyusunan KTSP, RKK, RKM, SKH \\
\hline Kurikulum & $\begin{array}{l}\text { kurikulum: Guru dan } \\
\text { Kepala PAUD }\end{array}$ & 2.Disahkan oleh Kepala PAUD \\
\hline $\begin{array}{l}\text { Implementasi } \\
\text { Kurikulum }\end{array}$ & Guru & $\begin{array}{l}\text { 1. Melaksanakan perencanaan, pelaksanaan, } \\
\text { dan penilaian pembelajaran } \\
\text { 2. Memberikan muatan Islam dan mengacu } \\
\text { pada Al Quran dan Hadits } \\
\text { 3. Mengacu Metode Montessori yang } \\
\text { mengharagai keunikan anak didik }\end{array}$ \\
\hline $\begin{array}{l}\text { Evaluasi } \\
\text { Kurikulum }\end{array}$ & Kepala PAUD dan Guru & $\begin{array}{l}\text { 1. Dilakukan berdasarkan hasil } \\
\text { pengalaman guru dan pengawasan oleh } \\
\text { Kepala PAUD } \\
\text { 2. Evaluasi kurikulum digunakan untuk } \\
\text { menyusun kurikulum tahun ajaran } \\
\text { selanjutnya }\end{array}$ \\
\hline
\end{tabular}

Sumber: dioleh dari data penelitian

Pertama, dalam konteks kurikulum sebagai dokumen perencanaan, terdapat rangkaian tindakan yang dilakukan oleh PAUD RBP dalam merancang kurikulumnya setiap tahun, yaitu:

a. Membentuk Tim Pengembang Kurikulum yang disahkan oleh lembaga satuan, yang akan menyusun kurikulum tahun ajaran baru. Perubahan kurikulum dengan tahun sebelumnya mempertimbangkan visi misi, evaluasi kurikulum tahun lalu, analisis SWOT, perkembangan siswa, dan perkembangan sosial-budaya.

b. Tim pengembang kurikulum menyusun KTSP, membuat rencana besar dan tema besar pada kurikulum untuk semester I dan semester II. Tema didasarkan oleh tema pada kurikulum nasional yang sesuai dengan kondisi satuan dan peserta didik. KTSP kemudian dipecah menjadi Rencana Kegiatan Kuartal (RKK).

c. Semua guru membagi tugas dalam menyusun Rencana Kegiatan Mingguan (RKM), dan Satuan Kegiatan Harian (SKH) berdasarkan rencana besar dan tema besar yng dikembangkan oleh tim.

d. Dilakukan review, revisi, dan penetapan pada setiap dokumen kurikulum

e. Dokumen kurikulum disahkan oleh kepala PAUD.

Kedua, Setelah perencanaan, kurikulum kemudian diimplementasikan oleh guru dengan merancang perencanaan pembelajaran, pelaksanaan pembelajaran, dan penilaian. Implementasi kurikulum di PAUD RBP mengacu pada Kurikulum Montessori yang diterapkan di London, sesuai dengan pengalaman Kepala PAUD RBP. Langkah-langkah terdiri dari menyambut anak, circle time, kegiatan mandiri, makan bersama, hingga kegiatan terpimpin. Akan tetapi semua kegiatan tersebut diberikan muatan nilai-nilai Islam.

Misalnya dalam perencanaan pembelajaran, guru selalu mencantumkan kegiatan berdoa maupun pembiasaan lainnya terkait akidah/ibadah. Sebagai PAUD dengan Kurikulum Montessori Bernafaskan Islam, seluruh materi maupun kegiatan harus dikemas secara islami 
meskipun materi yang disampaikan bukanlah mengenai praktik Ibadah. Saat mengajarkan sains, misalnya, nama Allah harus disebut sebagai pencipta alam, pencipta sifat alam, pencipta apapun yang terlihat anak, bahkan pencipta diri anak itu sendiri. Dari sini, anak mengenal tentang akidah. Pembiasaan ibadah pun disertai ke dalam semua kegiatan pembelajaran. Setiap memulai kegiatan guru mengucapkan bismilah dan mengakhiri dengan alhamdulilah. Pembacaan doa juga mengawali hari dan sebelum pulang. Semua pengemasan kegiatan secara islami itu tertera pada perencanaan pembelajaran yang akan dilaksanakan guru dalam kegiatan belajar mengajar.

Selain memberikan muatan nilai-nilai Islam, guru juga menerapkan prinsip-prinsip Metode Montessori dalam mengimplementasikan kurikulum. Oleh karena itu, dalam tahap merancang perencanaan pembelajaran guru menghargai keunikan individu tiap-tiap peserta didik. Perencanaan pembelajaran yang bersifat individu dirancang guru dengan mengacu pada hasil observasi guru terhadap anak. Observasi dilakukan untuk mengetahui minat, bakat, maupun perkembangan anak. Anak didik baru diobservasi melalui hasil wawancara guru terhadap orang tua, isian formulir oleh orang tua, dan hasil psikotest. Sementara anak didik yang sudah masuk kelas diamati saat melaksanakan pembelajaran. Dengan demikian guru dapat merencanakan bentuk stimuli yang diberikan sesuai dengan keunikan anak.

Setelah perencanaan, implementasi kurikulum selanjutnya adalah pelaksanaan pembelajaran. Dalam tahap ini, guru melaksanakan pembelajaran berdasarkan perencanaan yang ia buat. Saat melaksanakan pembelajaran guru tidak hanya berperan sebagai fasilitator dan koordinator, tapi juga harus mampu menjadi suri teladan kepada anak yang tindakannya harus mengacu pada Alquran dan Hadits. Misalnya memakai busana yang tertutup aurat, selalu membaca Basmalah saat memulai kegiatan dan Hamdalah saat mengakhiri kegiatan, murah senyum, dan lainnya. Guru juga melakukan pembiasaan nilai moral Islam terhadap anak dalam pergaulan sehari-hari; misalnya dalam menyelesaikan konflik, memuji, dll.

Demikian juga dalam penilaian, aspek Praktek Ibadah/Pengenalan Aqidah menjadi salah satu yang dilaporkan pada Laporan Mingguan, Laporan Kuartal, dan Laporan Semester.

Ketiga, Setelah implementasi, tahap pengembangan kurikulum selanjutnya adalah evaluasi kurikulum. Evaluasi kurikulum dilakukan berdasarkan pengalaman guru dalam mengimpelementasikan kurikulum dan juga berdasarkan hasil pengawasan Kepala PAUD terhadap implementasi kurikulum, yang kemudian dikaji dengan analisis SWOT.

Di PAUD RBP, Kepala PAUD juga harus melakukan evaluasi formatif dan sumatif terhadap guru. Ini terkait dengan kedudukan Kepala PAUD yang dianggap sebagai sumber pengetahuan kurikulum bagi guru. Hal ini terkait dengan pengalaman dan latar belakang pendidikan yang dimiliki Kepala PAUD mengenai kurikulum Montessori. Oleh karena itu, Kepala PAUD memainkan peran sebagai pengawas kinerja guru sekaligus pengawas implementasi kurikulum. Evaluasi kurikulum digunakan untuk bahan revisi penyusunan kurikulum tahun ajaran selanjutnya.

\section{Pembahasan}

\section{Perbandingan Pendidikan dalam Islam dengan Metode Montessori}

Membandingkan antara Pendidikan dalam Islam dengan Metode Montessori, keduanya memiliki banyak keselarasan dibandingkan pertentangannya. Akan tetapi perbedaan tersebut merupakan hal yang paling prinsipil bagi Islam, yakni ketiadaan unsur keimanan pada Metode Montessori.

Montessori memiliki sistem pendidikan sekuler, yang artinya tidak mengajarkan agama secara khusus di dalam kurikulum. Meskipun demikian, Metode Montessori menghormati semua agama. Oleh karena itu, banyak sekolah Montessori yang merayakan berbagai hari raya keagamaan, seperti Idul Fitri, Natal, dan Tahun Baru Cina. Akan tetapi perayaan itu tidak dipandang sebagai pembelajaran agama/keimanan, tapi merupakan pembelajaran budaya 
mengenal berbagai agama yang ada di lingkungannya (Gettman, 2016; Montessori Australia Foundation, 2021).

Dapat dikatakan Metode Montessori berkarakteristik seperti pandangan Barat lainnya. Pada umumnya, Pendidikan Barat dan liberal hanya berfokus pada kebenaran secara sosial dan empiris, sementara kebenaran dalam pandangan Islam lebih luas. Dalam Islam, kebenaran berdasarkan bukti empiris dan sosial diakui sebagai penalaran melalui akal, yang merupakan bagian penting bagi pengetahuan. Akan tetapi, di luar itu ada kebenaran hakiki yang memiliki tingkatan yang lebih tinggi, yaitu kebenaran yang datang langsung dari Allah SWT melalui wahyu kepada nabi dan rasul. Hal itu menjadi perbedaan mencolok di antara keduanya. (Burde et al., 2015; Rayan, 2012).

Singkatnya, pendidikan dalam Islam tidak hanya mencakup aspek intelektualitas tapi juga akidah (keimanan), syariah (pengalaman ibadah), dan akhlak (etika moral Islam). Lebih lengkapnya, pendidikan dalam perspektif Islam didefinisikan ilmuwan (ulama) ke dalam tiga dimensi istilah, yaitu tarbiyyah, yakni proses pendidikan, pemeliharaan, dan pengasuhan yang menekankan pengembangan fisik dan intelektual; ta'dib, yaitu proses pendidikan yang memberikan penekanan pada pemeliharaan manusia dengan etika mulia, sehingga seseorang dapat menempatkan diri di tengah masyarakat atau yang disebut bersopan-santun dan beradab; dan ta'lim, yaitu proses pendidikan yang menekankan pada pengajaran dan pembelajaran (transfer of knowledge). Konsep dan praktik pendidikan dalam Islam harus mempertimbangkan ketiga dimensi tersebut (Mohammad Muchlis, 2007; Yasin \& Jani, 2013; Zamroni, 2017).

Berangkat dari perbedaan tersebut, maka tujuan pendidikan di antara keduanya pun menjadi berbeda. Tujuan pendidikan Metode Montessori hanya mencakup hal keduniawian, yakni anak tumbuh menjadi manusia yang membawa tatanan sosial yang lebih baik. Tujuan itu tidak bertentangan dengan Islam. Dalam Islam, manusia terbaik adalah yang memberikan manfaat. Sebagaimana yang disampaikan Nabi Muhammad SAW, "Sebaik baik manusia adalah yang paling bermanfaat bagi orang lain" (HR. Qudhy dari Jabir dalam Khulaisie, 2016, p. 86). Akan tetapi, tidak cukup hanya disitu, pendidikan dalam Islam tidak hanya bertujuan untuk dunia tapi juga akhirat yaitu mendapatkan keselamatan dunia akhirat (Padjrin, 2016). Oleh karena itulah dalam memadukan Islam dan Metode Montessori diperlukan penyusunan kurikulum yang holistik untuk memenuhi seluruh aspek.

Selanjutnya, dalam melaksanakan pendidikan anak dalam Islam terdapat terminologi yang sering disebut, yakni fitrah. Setiap manusia terlahir dengan fitrahnya, sebagaimana difirmankan Allah SWT, "Maka hadapkanlah wajahmu dengan lurus kepada agama (Islam); (sesuai) fitrah Allah disebabkan Dia telah menciptakan manusia menurut (fitrah) itu. Tidak ada perubahan pada ciptaan Allah. (Itulah) agama yang lurus, tetapi kebanyakan manusia tidak mengetahui (Q.S Ar-Rum:30). Ayat tersebut menunjukkan seorang anak tercipta dengan fitrahnya. Oleh karena itu, mendidik sesuai fitrah merupakan sesuatu yang penting dalam Islam. Fitrah dapat dikaitkan dengan potensi anak. Ditegaskan oleh Ahmad Tafsir (dalam Mohammad Muchlis, 2007) bahwa fitrah adalah potensi, dan potensi adalah kemampuan.

Setiap anak memiliki potensi yang berbeda-beda. Oleh karena itu dalam pandangan Islam, pendidikan dalam Islam bersifat humanis dan amat menghormati perbedaan. Aspek perbedaan harus menjadi titik pijak dan titik tekan bagi setiap pendidik. Pendidik harus sadar betul bahwa masing-masing peserta didik merupakan manusia yang unik yang tidak persis sama. Oleh karena itu tidak boleh ada penyeragaman-penyeragaman dan peserta didik harus diberikan ruang agar mampu mengekspresikan perbedaan tersebut pada semua aspek kehidupan (Rahbini, 2013).

Dikaitkan dengan Montessori, mendidik anak sesuai fitrahnya selaras dengan konsep Metode Montessori yang menghargai keunikan anak. Menghargai keunikan anak diaplikasikan dengan memberi kebebasan memilih sehingga anak dapat mandiri dan berpikir. Kebebasan ini akan memberikan kepuasan, yang mana menjadi penghargaan secara instristik (dari dalam diri). Montessori menyadari dan percaya bahwa kondisi bebas memilih dan proses dalam belajar merupakan penghargaan sejati yang dibutuhkan anak (Lillard, 2013). 
Berbicara mengenai kebebasan dalam belajar, hal ini juga selaras dengan pendidikan dalam Islam. Allah SWT tidak pernah mewajibkan manusia untuk menjadi seorang ekonom, ilmuwan, akademisi, dokter, ataupun wirausahawan. Manusia diberikan kebebasan untuk mempelajari ilmu apapun, tapi wajib untuk beriman dan bertakwa (Aslam, 2017). Ini selaras dengan firman Allah SWT yang menyatakan bahwa tujuan keberadaan manusia adalah untuk beribadah: "Dan Aku tidak menciptakan jin dan manusia melainkan supaya mereka beribadah kepada-Ku." (QS. Adz Dzariyat: 56). Unsur keimanan inilah yang kembali menjadi faktor pembeda antara Pendidikan dalam Islam dan Montessori.

Untuk mencapai tujuan, lingkungan menjadi sesuatu yang penting, baik dalam Islam maupun menurut Metode Montessori. Terdapat keselarasan antara keduanya ketika orang dewasa (orang tua, guru) dan teman ditempatkan sebagai lingkungan yang berpengaruh pada perkembangan anak. Perbedaannya adalah dari segi fungsi dan peran. Dalam Islam, keteladanan menjadi penekanan dalam peran orang tua dan guru. Sementara dalam Metode Montessori orang dewasa bertugas sebagai fasilitator dan pengamat. Untuk teman, dalam Islam diyakini bahwa teman yang baik memberikan pengaruh yang baik pula dalam pembentukan karakter anak. Sementara itu, dalam Metode Montessori teman akan memberikan stimuli yang membantu perkembangan anak. Dengan konsep tanpa pengelompokan usia, di kelas Montessori anak-anak yang lebih muda akan mendapatkan stimuli dari anak yang lebih tua, sementara anak yang lebih tua mendapatkan keuntungan dalam menjalan perannya sebagai panutan (Liliard dalam Ansari \& Winsler, 2014).

Terkait dengan lingkungan "siapan" Montessori berupa lingkungan terstruktur berupa alat bekerja yang disusun secara teratur, Islam mendukungnya proses pembelajaran yang berjenjang atau bertingkat. Seperti yang difirmankan Allah SWT, "Sungguh, akan kamu jalani tingkat demi tingkat (dalam kehidupan)" (QS al-Insyiqaq:19).

Sedikit perbedaan terkait lingkungan, dalam Islam anak diperbolehkan mendapatkan penghargaan dari orang tua ataupun guru untuk memotivasi diri anak dalam belajar. Berbeda dengan itu, Metode Montessori tidak memberikan penghargaan eksintrik sebagai sumber motivasi belajar. Hal ini bisa jadi dipandang sebagai sesuatu yang bertentangan. Namun, Penulis lebih memandang hal ini sebagai keyakinan Montessori yang menganggap pemberian penghargaan sebagai sesuatu yang tidak efektif.

Keyakinan ini berdasarkan pengalaman Montessori saat memberikan hadiah kepada anak didiknya di kelas. Montessori awalnya mengira anak membutuhkan hadiah, tapi ketika anak mengabaikan hadiah yang diberikan, dan meminta lebih banyak kata untuk dibaca, Montessori menjadi percaya bahwa, di bawah kondisi pilihan bebas, belajar adalah hadiahnya sendiri. Dia kemudian menghilangkan penghargaan ekstrinsik dari program tersebut (Lillard, 2013).

\section{Landasan Pengembangan Kurikulum Montessori Islami}

Dalam menyusun kurikulum, tentunya diperlukan landasan kurikulum. Landasan pada kurikulum diibaratkan fondasi bangunan. Semakin kokoh fondasi, semakin kokoh pula bangunan tersebut. Demikian pula pada kurikulum. Semakin kokoh landasan kurikulum, maka akan semakin kuat pula kurikulum tersebut. Menurut Hornby dkk. (dalam Sukirman \& Asra, 2016) landasan merupakan gagasan atau kepercayaan yang menjadi sasaran, dasar, titik tolak, suatu prinsip yang mendasari. Dengan demikian landasan pengembangan kurikulum dapat diartikan sebagai suatu gagasan, suatu asumsi, atau suatu prinsip yang menjadi dasar atau titik tolak dalam mengembangkan kurikulum.

Berdasarkan hasil penelitian, pemikiran, prinsip, dan sikap Kepala PAUD terhadap pendidikan kepada anak diterjemahkan oleh PAUD RBP sebagai landasan kurikulum. Landasan kurikulum tersebut adalah Islam. Sementara Montessori adalah landasan pendukungnya. Dengan menempatkan Islam sebagai landasan utama, maka cara pandang penyusunan kurikulum di PAUD Rumah Bermain Padi adalah pendidikan yang islami, sesuai dengan tuntunan Al-Quran dan Hadist, yang mana adalah suatu keharusan dalam pendidikan berperspektif Islam (Atabik \& Burhanuddin, 2015; Nurhayati \& Syahrizal, 2015). 
Islam harus ditempatkan sebagai yang utama karena Islam mensyaratkan keimanan (akidah) secara mutlak kepada Allah SWT dan Rasul. Seseorang yang beriman dituntut untuk bertakwa sebagai bentuk kepatuhan. Ketakwaan bukanlah suatu pilihan bagi seorang muslim, tapi suatu keharusan. Sebagaimana Allah berfiman, "Hai sekalian manusia, bertakwalah kepada Tuhanmu yang telah menciptakan kamu dari seorang yang satu..." (QS. An-Nisaa:1). Oleh karena itu, ketika Metode Montessori memiliki sikap terbuka dan menerima semua nilai lokal yang berlaku, nilai-nilai Islam mengharuskan penyusun kurikulum untuk menelaahnya terlebih dahulu. Apakah nilai tersebut sesuai dengan Islam atau tidak. Jika tidak sesuai, maka wajib ditinggalkan. Jika tidak, maka hilanglah identitas keislamannya.

Dari landasan kurikulum, maka tujuan pendidikan kemudian dapat ditentukan Di PAUD RBP, tujuan pendidikan tercermin dalan visi dan misi PAUD RBP., tahap merumuskan tujuan memberikan landasan yang penting pada kurikulum. Tujuan akan mengarahkan tentang konten apa yang penting dan bagaimana konten itu diorganisasi. Selain tujuan, penentuan dan pengorganisasian konten juga melibatkan kriteria lain, seperti validitas (keabsahan), makna (signifikansi), perbedaan yang tepat antara berbagai tingkatan dan konten, dan tingkat perkembangan. Lebih jauh lagi, kontinuitas dan urutan dalam belajar dan variasi kapasitas belajar penting pula untuk dipertimbangkan (Bahri, 2014; Kuboja \& Ngussa, 2015; Taba, 1962).

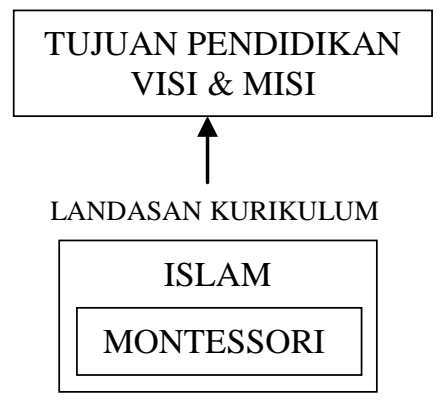

Gambar 1. Landasan Kurikulum dan Tujuan Pendidikan di PAUD Rumah Bermain Padi

Membedah visi PAUD RBP, menjadi rahmatan lil alamin adalah menjadi rahmat bagi semesta alam. Hal ini merupakan suatu visi yang dibawa oleh Rasulullah SAW sebagai utusan Allah yang mana difirmankanlah Allah SWT, "Dan tiadalah Kami mengutus kamu, melainkan untuk (menjadi) rahmat bagi semesta alam." (Qs. Al.Anbiya: 107).

Pemaknaan ayat di atas kemudian bermuara pada konsep Islam sebagai rahmatan lil alamin. Pendidikan yang rahmatan lil alamin akan membawa pada anak didik yang dapat menjadi rahmatan lil alamin pula. Dengan konsep tersebut, diharapkan dampak dari pendidikan menurut Islam pun tercapai, yaitu mengantarkan kemajuan umat. Dalam konteks pendidikan Islam, "mengantarkan kemajuan umat" adalah memberikan manfaat atau menjadi rahmatan lil alamin. (Rayan, 2012; Salleh \& Khamis, 2010).

Mengenai misi PAUD RBP, misi tersebut mencerminkan 1) sifat pendidikan dalam Islam yang holistik, yang mana pendidikan bertujuan agar anak didik menemukan keseimbangan antara fisik, mental, intelektual, psikologis, jiwa, dan spiritual. (Rayan, 2012; Salleh \& Khamis, 2010). 2) penekanan terhadap akidah dan akhlak. 3) Pembelajaran dengan memaksimalkan potensi yang dalam pandangan Islam merupakan fitrah anak. Sejalan dengan pandangan Montessori, yakni pendidikan pada anak harus dilakukan dengan memanfaatkan seluruh indera anak yang pada masa awal enam tahun kehidupan sedang sensitif terhadap input pada seluruh inderanya dan menyerap apapun yang di dunia (Ahmad, 2016; Montessori, 2008; Rathunde, 2001).

Sebagai tujuan pendidikan, visi misi PAUD RBP memiliki peran yang penting terhadap pengembangan kurikulum di satuan pendidikan tersebut. Selaras dengan Zais (1976) yang menyatakan tujuan (aims, goals, dan objectives) merupakan salah satu komponen kurikulum yang menempati posisi sangat sensitif terhadap kekuatan-kekuatan mendasar kurikulum. Tidak 
hanya karena menentukan bentuk kurikulum, tapi juga karena tujuan memberikan petunjuk dan arah untuk menghasilkan outcomes yang diharapkan.

\section{Pengembangan Kurikulum Montessori Islami}

Dalam mengembangkan kurikulum, langkah-langkah yang dilakukan adalah perencanaan, implementasi, dan evaluasi kurikulum. Berikut bagan yang menggambarkannya:

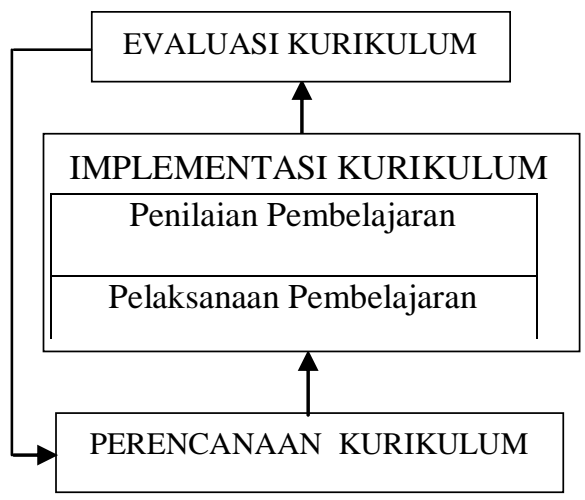

Gambar 2. Alur Pengembangan Kurikulum di PAUD Rumah Bermain Padi

Pada perencanaan kurikulum di PAUD RBP, hal-hal yang menjadi pertimbangan PAUD adalah visi misi, evaluasi kurikulum tahun lalu, analisis SWOT, perkembangan siswa, dan perkembangan sosial-budaya. Artinya, perencanaan dilakukan berdasarkan tujuan pendidikan dan analisis kebutuhan.

Dalam mengembangkan kurikulum, analisis kebutuhan perlu dilakukan baik kebutuhan anak didik maupun masyarakat atau lingkungan. Semakin dalam anak didik dianalisis, maka semakin besar pula kemampuan pengembang kurikulum untuk merancang pembelajaran yang sesuai dengan anak didik dan mengetahui apa yang harus dipelajari dan bagaimana menyampaikannya kepada anak didik. Terkait masyarakat, satuan pendidikan perlu menyerap dan melayani aspirasi-aspirasi yang ada di masyarakat sehingga dapat mengakomodasi kebutuhan masyarakat terhadap satuan pendidikan (Dick \& Carey, 2009; Sukmadinata, 2012; Tyler dalam Wahyudin, 2014).

Di PAUD RBP, analisis terhadap anak didik merupakan bentuk dari penerapan Kurikulum Montessori yang berpusat pada anak. Kurikulum yang berpusat pada anak adalah kurikulum yang menghargai keunikan anak. Paham dari kurikulum ini menganggap pengetahuan berasal dari pengalaman pribadi anak. Oleh karena itu, guru perlu mengenal kebutuhan dan minat anak melalui pengamatan yang cermat untuk membantu anak membangun pengalaman pribadi secara aktif (Ornstein \& Hunkins, 2013).

Pada implementasi kurikulum di PAUD RBP, pihak yang melaksanakannya adalah guru. Ini sesuai dengan berbagai literatur yang menempatkan guru sebagai implementator kurikulum. Seperti yang dinyatakan Rusman (2009) yang menyatakan guru merupakan pengembang kurikulum yang sebenarnya karena guru adalah implementator kurikulum yang bertindak sebagai perencana, pelaksana, dan penilai pembelajaran. Begitupun dengan Tarr et al., (2013) yang mengatakan guru adalah pengembang aktif dari kurikulum yang ditetapkan. Oleh karena itu guru merupakan letak kunci keberhasilan kurikulum. Kekuatan atau komptensi guru seperti pengetahuan guru, kepercayaan guru dan penggunaan sumber daya lainnya oleh guru akan sangat mempengaruhi implementasi kurikulum.

Setelah implementasi, tahap selanjutnya adalah evaluasi kurikulum. Evaluasi pelaksanaan kurikulum tidak hanya mengevaluasi peserta didik dan proses pembelajarannya, tetapi juga rancangan dan pelaksanaan kurikulum, tujuan, sub judul, kemampuan dan kemajuan siswa, sarana dan prasarana, keefektifan pengajaran, serta sumber belajarnya. Dengan adanya evaluasi, maka perencana kurikulum dapat menetapkan apakah tujuan sekolah dan tujuan pengajaran telah tercapai serta mengetahui kelebihan dan kelemahan kurikulum sehingga 
diharapkan dapat ditindaklajuti menuju perbaikan di masa yang akan datang (Ibrahim \& Masitoh, 2016; Rusman, 2009; Saylor dkk dalam Wahyudin, 2014).

Salah satu tindakan yang dilakukan oleh PAUD RBP untuk mengevalusi kurikulum adalah dengan melakukan analisis SWOT, yaitu analisis yang menggunakan pendekatan strengths (kekuatan), weakness (kelemahan), opportunity (peluang) threats (ancaman). Dengan mengaplikasikannya pada evaluasi kurikulum, maka satuan pendidikan bisa memaksimalkan kekuatan dan peluang sekaligus meminimalisir kelemahan dan ancaman (Gitosudarmo, 2001; Rangkuti, 2013). Hasil ini kemudian digunakan PAUD RBP untuk perbaikan kurikulum tahun ajaran selanjutnya, yang artinya tahap evaluasi dikembalikan ke titik asal (umpan balik), membuat suatu lingkaran (loop). Hal ini akan memudahkan penyempurnaan lebih lanjut pada pengembangan kurikulum selanjutnya.

\section{Simpulan dan Saran}

Pendidikan dalam Islam dan Metode Montessori dapat dijalankan secara selaras. Kurikulum Montessori yang menghargai potensi dan keunikan anak selaras dengan konsep mendidik anak sesuai fitrah dalam Islam. Kedua perspektif ini juga sepakat bahwa orang tua, guru, dan lingkungan fisik dan sosial merupakan lingkungan pendidikan yang penting bagi perkembangan anak.

Berdasarkan hasil penelitian, Rekonstruksi Kurikulum Montessori di PAUD RBP dapat digambarkan sebagai berikut:

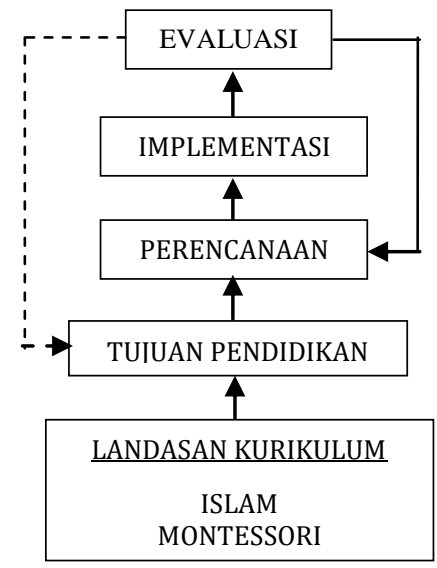

Gambar 3. Rekonstruksi Kurikulum Montessori Islami di PAUD Rumah Bermain Padi

Gambar 3 menunjukkan landasan kurikulum merupakan acuan dalam merekonstruksi Kurikulum Montessori di PAUD RBP. Landasan utama kurikulum adalah Islam, sementara Metode Montessori adalah landasan pendukungnya. Ini memberi konsekuensi bahwa jika ada nilai-nilai pada Metode Montessori yang tidak sesuai dengan Islam,, maka hal itu tidak boleh dijalankan. Hanya prinsip yang selaras dengan Islam saja yang aplikasikan ke dalam Kurikulum Montessori Islami.

Selanjutnya, landasan menjadi acuan dalam merumuskan tujuan pendidikan dan pengembangan Kurikulum Montessori Islami. Berdasarkan landasan tersebut, inti dari tujuan pendidikan PAUD RBP adalah membimbing anak untuk menjadi rahmatan lil alamin. Dari tujuan pendidikan, kemudian tim pengembang kurikulum merumuskan perencanaan kurikulum berupa KTSP, yang mana kemudian guru mengimplementasikannya ke dalam wujud perencanaan pembelajaran, pelaksanaan pembelajaran, dan penilaian. Implementasi kurikulum dilakukan dengan memperhatikan keunikan individu anak, dan guru bertindak sebagai fasilitator dan pengamat. Tahap terakhir adalah evaluasi menggunakan analisis SWOT yang hasilnya digunakan untuk penyempurnaan pengembangan kurikulum selanjutnya. 
Saran dari penelitian ini adalah dilakukannya penelitian lebih lanjut mengenai pengembangan kurikulum PAUD di negara Islam, bukan adaptasi dari Pendidikan Barat. Ini bisa menjadi perbandingan terhadap Kurikulum Montessori Islami.

\section{Daftar Rujukan}

Ahmad, J. M. (2016). Filosofi Montessori [Modul Pelatihan].

Ansari, A., \& Winsler, A. (2014). Montessori Public School Pre-K Programs and the School Readiness of Low-Income Black and Latino Children. Journal of Educational Psychology, 106(4), 1066-1079. https://doi.org/10.1037/a0036799

Aslam, A. (2017). Individu, Kebebasan Memilih, dan Toleransi dalam Alquran. In N. El Harmouzi \& L. Whetstone (Eds.), Islam dan Kebebasan Berpikir: Argumen Islam untuk Masyarakat Bebas (1st ed., pp. 81-106). Suara Kebebasan.

Atabik, A., \& Burhanuddin, A. (2015). Konsep Nasih Ulwan tentang Pendidikan Anak. Elementary, 3(2), 274-296. https://doi.org/10.21043/elementary.v3i2.1454

Azkia, N., \& Rohman, N. (2020). Analisis Metode Montessori dalam Meningkatkan Kemampuan Membaca Permulaan Siswa Kelas Rendah SD/MI. Ar-Riayah: Jurnal Pendidikan Dasar, 4(1), 1-14. https://doi.org/http://dx.doi.org/10.29240/jpd.v4i1.1411

Bahri, S. (2014). Pengembangan Kurikulum Dasar Dan Tujuannya. Jurnal Ilmiah Islam Futura, 11(1), 15. https://doi.org/10.22373/jiif.v11i1.61

Burde, D., Middleton, J. A., \& Wahl, R. (2015). Islamic Studies as Early Childhood Education in Countries Affected by Conflict: the Role of Mosque Schools in Remote Afghan Villages. International Journal of Educational Development, 41, 70-79. https://doi.org/10.1016/j.ijedudev.2014.10.005

Creswell, J. W. (2014). Research Design: Qualitative, Quantitative, and Mixed Methods Approaches. Sage Publications.

Dick, W., \& Carey, L. (2009). The Systematic Design of Instruction. Pearson.

Gettman, D. (2016). Metode Pengajaran Montessori Tingkat Dasar: Aktivitas Belajar untuk Anak Balita (A. Nuriowandari (trans.)). Pustaka Pelajar.

Gitosudarmo, I. (2001). Manajemen Keuangan. BPFE.

Gumiandari, S., Nafi'a, I., \& Jamaluddin, D. (2019). Criticizing Montessori's Method of Early Childhood Education using Islamic Psychology Perspective. Jurnal Pendidikan Islam, 5(2), 133-148. https://doi.org/10.15575/jpi.v5i2.5835

Hiles, E. (2018). Parents' Reasons for Sending Their Child to Montessori Schools. Journal of Montessori Research, 4(1), 1-13. https://doi.org/10.17161/jomr.v4i1.6714

Hilson, P. F. (1982). Montessori' s Concept of The Spiritual Embryo. Montessori Australia, May, 1-7. https://montessoridigital.org/file/2005/download?token=vxz1WT5J

Ibrahim, \& Masitoh. (2016). Evaluasi Kurikulum. In Tim Pengembang MKDP Kurikulum dan Pembelajaran (Ed.), Kurikulum \& Pembelajaran (pp. 105-121). Rajagrafindo Persada.

Jailani, M. S. (2014). Teori Pendidikan Keluarga dan Tanggung Jawab Orang Tua dalam Pendidikan Anak Usia Dini. Jurnal Pendidikan Islam, 8(2), 245-260. https://doi.org/10.21580/nw.2014.8.2.580

Julita, D., \& Susilana, R. (2018). Implementasi Kurikulum Montessori Bernafaskan Islam pada Pendidikan Anak Usia Dini Rumah Bermain Padi di Kota Bandung. Jurnal Penelitian Ilmu Pendidikan, 11(2), 149-163. https://doi.org/https://doi.org/10.21831/jpipfip.v11i2.24201

Khulaisie, R. N. (2016). Hakikat Kepribadian Muslim , Seri Pemahaman Jiwa Terhadap Konsep Insan Kamil. Jurnal Refletika, 11(11), 39-57. http://jurnal.umk.ac.id/index.php/RE/article/download/447/478

Kuboja, J. M., \& Ngussa, B. M. (2015). Conceptualizing the Place of Technology in Curriculum Formation: A View of the Four Pillars of Curriculum Foundations. International Journal of Academic Research in Progressive Education and Development, 4(2). https://doi.org/10.6007/IJARPED/v4-i2/1728

Lillard, A. S. (2013). Playful Learning and Montessori Education. American Journal of Play, 
5(2), 157-186. http://www.journalofplay.org/sites/www.journalofplay.org/files/pdfarticles/5-2-article-play-learning-and-montessori-education_0.pdf

Mohammad Muchlis, S. (2007). Fitrah; Konsep Dan Pengembangannya Dalam Pendidikan Islam. Tadrîs, 2(2), 236-249. https://doi.org/10.19105/jpi.v2i2.219

Moleong, L. J. (2017). Metode Penelitian Kualitatif. PT. Remaja Rosdakarya.

Montessori Australia Foundation. (2021). How Does Montessori Approach Religion. Montessori Australia Group. https://montessori.org.au/how-does-montessori-approachreligion

Montessori, M. (2004). The Discovery of The Child (M. A. Johnstone (trans.)). Aakar Books.

Montessori, M. (2008). Absorbent Mind: Pikiran yang Mudah Menyerap (Dariyatno (trans.)). Pustaka Pelajar.

Nurhayati, \& Syahrizal. (2015). Urgensi dan Peran Ibu Sebagai Madrasah Al- Ula dalam $\begin{array}{llll}\text { Pendidikan Anak. } & \text { Itqan, }\end{array}$ http://ejurnal.iainlhokseumawe.ac.id/index.php/itqan/article/download/49/45

Ornstein, A. C., \& Hunkins, F. P. (2013). Curriculum: Foundations, principles, and Issues. Pearson Education.

Padjrin. (2016). Pola Asuh Anak dalam Perspektif Pendidikan Islam. Intelektualita, 5(1), 1-14. https://doi.org/10.19109/intelektualita.v5i1.720

PAUD Rumah Bermain Padi. (2017). Kurikulum Tingkat Satuan Pendidikan PAUD Rumah Bermain Padi. Paud Rumah Bermain Padi.

Rahbini. (2013). Pendidikan Islam Berparadigma Rahmatan Lil'Alamin. Kariman, 01(01), 316.

Rangkuti, F. (2013). Analisis SWOT Teknik Membedah Kasus Bisnis. Gramedia Pustaka Utama.

Rathunde, K. (2001). Montessori Education and Optimal Experience: A framework for new research. The NAMTA Journal, 26(1), 11-43. https://pdfs.semanticscholar.org/2c6d/5cd47161ffb58b1aef14f622a2dcf336c130.pdf

Rayan, S. (2012). Islamic Philosophy of Education. International Journal of Humanities and Social Science, 2(19), 150-156.

Rusman. (2009). Manajemen Kurikulum. Rajagrafindo Persada.

Safitri, M. (2017). Konsep Reward dan Punishment dalam Mendidik Anak di Lingkungan Keluarga Menurut Ajaran Rasulullah SAW. In Universitas Islam Negeri Raden Fatah. Universitas Islam Negeri Raden Fatah.

Salleh, J., \& Khamis, M. H. (2010). The Philosophy and Objectives of Education in Islam [Proceedings of the Regional Conference on Islamic Education, Shah Alam, 24-25 July 2010]. International Islamic University Malaysia, 1-14.

Sanjaya, W. (2008). Kurikulum dan Pembelajaran. Prenadamedia Group.

Snyder, H. (2019). Literature review as a research methodology: An overview and guidelines. Journal of Business Research, 104(August), 333-339. https://doi.org/10.1016/j.jbusres.2019.07.039

Sukirman, D., \& Asra. (2016). Landasan Pengembangan Kurikulum. In Tim Pengembang MKDP Kurikulum dan Pembelajaran (Ed.), Kurikulum \& Pembelajaran (pp. 16-43). Rajagrafindo Persada.

Sukmadinata, N. S. (2012). Pengembangan Kurikulum: Teori dan Praktek. PT. Remaja Rosdakarya.

Sulaiman, A. (2014). Islamic Environment in Child Development According to The Views of Imam al-Ghazali. Mediterranean Journal of Social Sciences, 5(29), 33-39. https://doi.org/10.5901/mjss.2014.v5n29p33

Taba, H. (1962). Curriculum Development: Theory and Practice. Harcourt, Brace \& World, Inc.

Tarr, J. E., Grouws, D. A., Chávez, Ó., \& Soria, V. M. (2013). The Effects of Content Organization and Curriculum Implementation on Students' Mathematics Learning in Second-Year High School Courses. Journal for Research in Mathematics Education, 44(4), 683. https://doi.org/10.5951/jresematheduc.44.4.0683

Wahyudin, D. (2014). Manajemen Kurikulum. PT. Remaja Rosdakarya. 
Yasin, R. F. B. F., \& Jani, M. S. (2013). Islamic Education: The Philosophy, Aim, and Main Features. International Journal of Education and Research, 1(10), 1-16. http://irep.iium.edu.my/34152/1/Education_Paper_Airlangga.pdf

Zais, R. S. (1976). Curriculum: Principles and Foundations. Harper \& Row Publisher, Inc.

Zamroni, A. (2017). Strategi Pendidikan Akhlak pada Anak. Sawwa, 12(2), 241-264. https://doi.org/10.21580/sa.v12i2.1544 